\title{
THE MEDIATING ROLE OF EMPLOYEE JOB PERFORMANCE IN THE IMPACT OF OPEN BOOK MANAGEMENT DIMENSIONS ON CUSTOMER SATISFACTION
}

\author{
Faisal Abdulkarim ALKHAMIS \\ Department of Business Administration, College of Business \& Economics, \\ Qassim University, Buraidah, Saudi Arabia \\ E-mail:fakamis@gmail.com
}

Received 26 March 2018; accepted 17 June 2018

\begin{abstract}
This study aimed at investigating the impact of open book management (OBM) on customer satisfaction in the presence of employee job performance as a mediating variable. OBM was measured using employee empowerment, information sharing, employee training, and employee participation in organizational success. A sample consisted of 500 managers and employees from 10 industrial companies in Qassim region were participated in the study. Data were gathered using a questionnaire administered to participants. The final number of questionnaires received was 387 questionnaires with a response rate of 77.4 percent. The results showed positive as well as significant effects of employee training, empowerment and participation on employee job satisfaction and customer satisfaction. The results further pointed out that employee job performance mediated the effect of open book management dimensions on customer satisfaction. The originality of this study wells up from its contribution to literature as it underlined that employee training in the context of open book management should take the first priority, followed by employee empowerment as empowerment efforts do not bear its desired fruits in the absence of an employee who is able to properly implement what he or she empowered to do. It was recommended on the ground of these results to consider employee training, then employee empowerment in the context of OBM. An adoption of OBM is required to keep tabs on employee job performance in order to ensure an effective practice of OBM.
\end{abstract}

Keywords: open book management, employee performance, customer satisfaction.

JEL Classification: M12, O30.

\section{Introduction}

Renewed attention has been paid to open book management (OBM) as a management style due to the essence of this style in terms of managerial practices. It was defined as practice that make an organization's financial data and performance available for employees in order to be aware of its financial position. Although OBM definitions differ in terms of their terms, the content of these definitions is the same. Some researchers have focused on one aspect when defining open book management. An example of these definitions the one that describes OBM as "information sharing" between management and employees (Nikzad and Maryam 2012). Some of the other definitions took into account several aspects when describing OBM like employee training on using financial data, employee empowerment in decision-making process, giving employees the opportunity to contribute to their organization (Aggarwal and Simkins 2001).

The benefits of OBM have emerged as a result of studies conducted on the nature of the relationship between this OBM and other variables. These benefits include improving employee performance, enhancing employee knowledge and expertise, improving open communication, giving employees the opportunity to contribute to organizational goals, boosting employee creativity, and making better customer satisfaction (Ugboro and Obeng 2000, Yukl and Becker 2006, Bhatti and Qureshi 2007, Peters and Mazdarani 2008, Zhang and Bartol 2010, Spreitzer and

Copyright $\odot 2018$ The Authors. Published by VGTU Press.

This is an Open Access article distributed under the terms of the Creative Commons Attribution License (http://creativecommons.org/licenses/by/4.0/), which permits unrestricted use, distribution, and reproduction in any medium, provided the original author and source are credited. 
Porath 2012, Lee et al. 2012, Isimoya and Bakarey 2013, Elnaga and Imran 2013, Al-Mzary et al. 2015, Groen et al. 2016, Padmasiri et al. 2018).

Despite these results, studies that examined the effect of open book management on employee performance and consumer satisfaction are still few, especially in the Arab region and in the industrial sector in particular. On the other hand, previous studies have dealt with the concept of open book management as a composite variable. Hence, the present study aims to explore the effect of open book management on customer satisfaction in the presence of employee job satisfaction as a mediating variable. What distinguishes the current study from previous studies is that it studies OBM by focusing on its dimensions and not on the variable as a whole. Therefore, the study seeks to identify the impact of the dimensions of open book management on employee job performance and satisfaction of customers.

Based on previous studies, three dimensions of open management were selected in the current study: employee empowerment, employee training, and employee participation. Of course, the purpose of dividing open book management into these three dimensions is to identify the most dimension capable of influencing employee performance and customer satisfaction. The importance of this categorization will be clear in light of the study results, which will show the importance of one dimension for the rest of the dimensions. In fact, such a result helps organizations, identifying their priorities, i.e., whether or not training is offered on empowerment.

\section{Literature review and hypotheses development}

\subsection{Open book management definition and indicators}

OBM has been defined as a style of management that opens the organization's financial books so that employees know its returns, expenses and profit (Davis 1997). Nikzad and Maryam (2012) defined this term as a practice of information sharing between management and employees. Pfeffer and Veiga (1999) argued that the shared information in this context refers to information belongs to the organization's financial performance and strategies. For Evans and Davis (2005), OBM was considered as a mean to give employees an access to its financial information in order to be able to compare the degree of alignment of organizational goals with their goals. Spreitzer and Porath (2012) mentioned another benefit of OBM which was to give employees the opportunity to compare the degree of fitness between organizational strategies and their work. In relation to OBM dimensions, Nikzad and Maryam (2012) reported four of OBM, which were employee empowerment to make decisions, employees' direct participation in the organization's success, teaching employee on financial performance and performance measures as well as information sharing. Aggarwal and Simkins (2001) identified four steps of OBM implementation, which were information sharing with employees, management commitment and employee engagement in employee education and training, employee empowerment, and employee direct participation in the organization's success.

\subsection{EJP definition and indicators}

Rich et al. (2010) defined EJP in terms of activities that contribute directly to the achievement of organizational tasks or at least supports the achievement of these goals. In a study conducted by Yee (2018) on a sample of academic staff from private universities in Malaysia, two dimensions of employee job performance were identified, which were: behavioral and outcome dimensions. According to the author, the first dimension refers to employees' actions during work, while the second describes the results of their behavior. The author highlighted that the outcome aspect of employee job performance is the one that related to products and services produced on the basis of employees' knowledge and skills. Becker et al. (1996) measured employee job performance as a one factor. The items were related to work completion work, work quantity, work quality, work efficiency, satisfactory completion of work, and the overall degree of performance. Wright et al. (2007) indicated that the overall performance can be evaluated by asking each participant to rate his or her own performance over the past one year. According to Sturman et al. (2005), EJP can be measured based on supervisory evaluations or ratings, employee productivity and task performance.

\subsection{CS definition and indicators}

Danish et al. (2018) indicated that the main component of CS definition is customer expectations. The authors showed that the alignment of the actual performance of goods and services with customers' expectations results in satisfied customers. It was observed from the definitions of CS cited by Al-Tit (2015) that this variable describes the features that a product or a service provided in accordance with the customer's expectations. Therefore, satisfaction level requires that product experience meets or exceeds customer expectations. Söderlund and Oikarinen (2018) used three items to measure CS as a one factor, in which participants were asked to rate their degree of satisfaction.

\subsection{Open book management and employee job performance}

The relationship between OBM and employee job performance was investigated in numerous studies. Agbaeze and Nnaji (2017) evaluated the effect of OBM on employee performance using a sample consisted of 125 participants selected from industrial companies in Nigeria and found a 
positive effect of OBM on employee performance. Schuster et al. (1996) reported two major aspects of OBM, which were to motivate employees and to ensure their involvement in addition to financial performance enhancement. However, studies on open book management are few, but there were some studies that have taken into their account the relationship between open book management indicators such as employee empowerment, employee training, information sharing, and staff involvement in organizational success, and employee performance. Following Nikzad and Maryam (2012) and Aggarwal and Simkins (2001), OBM was conceptualized in the current study as a latent variable composed of three dimensions, i.e., employee empowerment, employee training and employee participation. According to Yukl and Becker (2006), empowering employees in the context of open book management is to entrust them and let them get the financial picture of the company through providing them with financial data such as revenues and profits. The authors stated that employee empowerment should be consummated by training in order to teach employees how to use the financial data to enhance organizational performance. For this study, employee participation was operationalized based on Glew et al.s (1995) definition of this concept. They recognized it as an extra effort that high level managers make to provide employees at lower levels with the opportunity to contribute to organizational performance. As for relationships among employee empowerment, training and participation and employee job performance, it was clarified in the literature that these variables were positively associated. Zhang and Bartol (2010) conducted a study on the information technology sector in China and found a positive indirect impact of employee empowerment on their creativity. In their study that took place on the Hotel sector in Taiwan, Chiang and Hsieh's (2012) revealed a positive impact of employee empowerment on their job performance. Effective training, for Elnaga and Imran (2013), Al-Mzary et al. (2015), Pradhan (2016) and Padmasiri et al. (2018), has a significant relationship with employee job performance. Bhatti and Qureshi (2007) and Groen et al. (2016) found a positive impact of employee participation on employee job performance. Al-Tit (2017) found a positive impact of other variables as organizational culture on organizational performance. Considering these results, the following hypotheses were suggested:

$\mathrm{H} 1$ : Employee empowerment is positively related to employee job performance

$\mathrm{H} 2$ : Employee training is positively related to employee job performance

$\mathrm{H} 3$ : Employee participation is positively related to employee job performance

\subsection{Open book management and customer satisfaction}

OBM has been introduced as a corporate strategy aimed at motivating employees to do their best in relation to organization's financial health. Three pivotal pillars were established as key aspects of OBM; employee empowerment, training and participation in order to make the organization a profitable one (Aggarwal and Simkins 2001). Research on employee empowerment and customer satisfaction has reported a positive impact of employee empowerment on customer satisfaction (Ugboro and Obeng 2000, Peters and Mazdarani 2008, Isimoya and Bakarey 2013). Some empirical studies have cited no relationship between these two variables (Naeem and Saif 2010, Jonathan and Johnmark 2012, Roy et al. 2017). Employee training, on the other hand, has been proved to positively predict customer satisfaction (Rogg et al. 2001, Molina and Ortega 2003, Chartrungruang et al. 2006). Based on these results, the following hypotheses were suggested:

H4: Employee empowerment is positively related to customer satisfaction

$\mathrm{H} 5$ : Employee training is positively related to customer satisfaction

H6: Employee participation is positively related to customer satisfaction

\subsection{Employee job performance and customer satisfaction}

The potential influence of employee job performance on customer satisfaction can be justified since employee job satisfaction relates to behaviors of employees that practiced in agreement with the organizational goals (Liao and Chuang 2004). According to Gillespie et al. (2008), both organizational goals and strategies should be directed to meet customers' needs. In a study conducted by Lee et al. (2012), the findings confirmed that customer satisfaction improvement can be achieved based on improvements made by the organization to ensure operations efficiency, employee engagement and service quality. Employees are crucial component in these improvements. In their study in mobile phone service providers in Pakistan, Abbasi and Alvi (2013) found a positive association between employee job performance and customer satisfaction. Additionally, Kattara et al. (2008) argued that both positive and negative behaviors of employee relate to customer satisfaction. Therefore, it was hypothesized that:

H7: Employee job performance positively related to customer satisfaction

\section{Research methodology}

\subsection{Research sample and data collection}

A stratified sample of 500 participants from industrial companies in Qassim was selected on the basis of their job titles, i.e., managers and employees. Within each managerial level, subjects were randomly selected. The sample included 100 managers and 400 employees. Questionnaires were 
administered to participants and collected over 2 weeks. Out of distributed questionnaires, 387 questionnaires were returned completed with a response rate of 77.4 percent.

\subsection{Research model}

The conceptual model of this study as shown in Figure 1 illustrated 7 hypothesized relationships among variables;

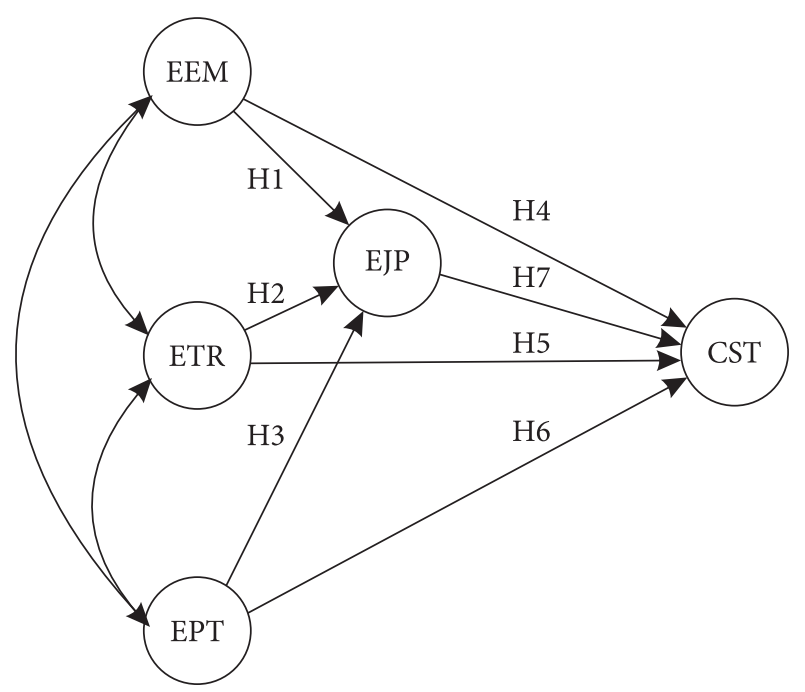

Figure 1. Research conceptual model (source: author's elaboration based on related works)

Table 1. Measures of research variables

\begin{tabular}{|c|c|c|}
\hline Variable & Measures & Source \\
\hline OBM & $\begin{array}{l}\text { - Information sharing } \\
\text { - Employee empower- } \\
\text { ment } \\
\text { - Employee training } \\
\text { - Employee direct } \\
\text { participation in orga- } \\
\text { nizational success. }\end{array}$ & $\begin{array}{l}\text { Davis (1997), Lloyd and } \\
\text { Case (1998), Pfeffer and } \\
\text { Veiga (1999), Aggarwal } \\
\text { and Simkins (2001), } \\
\text { Evans and Davis (2005), } \\
\text { Nikzad and Maryam } \\
(2012) .\end{array}$ \\
\hline EJP & $\begin{array}{l}\text { - Work quantity } \\
\text { - Work quality } \\
\text { - Employee behavior } \\
\text { - Work overall perfor- } \\
\text { mance }\end{array}$ & $\begin{array}{l}\text { Becker et al. (1996), } \\
\text { Wright et al. (2007), } \\
\text { Kattara et al. (2008). }\end{array}$ \\
\hline CS & $\begin{array}{l}\text { - Self-reported satis- } \\
\text { faction degree }\end{array}$ & $\begin{array}{l}\text { Al-Tit (2015), } \\
\text { Söderlund and } \\
\text { Oikarinen (2018), } \\
\text { Danish et al. (2018). }\end{array}$ \\
\hline
\end{tabular}

Table 2. Results of intraclass correlation coefficient

\begin{tabular}{|l|c|c|c|c|c|}
\hline \multirow{2}{*}{ Measures } & \multirow{2}{*}{$\begin{array}{c}\text { Intraclass } \\
\text { corre- } \\
\text { lations }\end{array}$} & \multicolumn{2}{|c|}{$\begin{array}{r}\text { 95\% Confidence } \\
\text { Interval }\end{array}$} & \multicolumn{2}{|c|}{ F-test } \\
\cline { 3 - 6 } & Lower bound & $\begin{array}{c}\text { Upper } \\
\text { bound }\end{array}$ & Value & Sig. \\
\hline $\begin{array}{l}\text { Single } \\
\text { measures }\end{array}$ & 0.430 & 0.330 & 0.534 & 5.309 & 0.000 \\
\hline $\begin{array}{l}\text { Average } \\
\text { measures }\end{array}$ & 0.790 & 0.711 & 0.851 & 5.039 & 0.000 \\
\hline
\end{tabular}

OBM dimensions (employee empowerment, training and participation) were assumed to have effects on employee job performance and customer satisfaction. Additionally, employee job performance was postulated to significantly predict customer satisfaction. The contribution of this model is that it tries to examine the effects of OBM dimensions on customer satisfaction considering employee job performance as a mediator variable.

\subsection{Measures}

OBM in this research was measured based on three indicators: employee empowerment, employee training and employee direct participation in organizational success (Aggarwal and Simkins 2001, Nikzad and Maryam 2012). Following Aggarwal and Simkins (2001), three items were used to assess each indicator of OBM. EJP was assessed using four indicators: work completion work, work quantity, work quality, work efficiency and overall performance (Becker et al. 1996, Wright et al. 2007). CS was measured using a self-reported satisfaction degree (Al-Tit 2015, Söderlund and Oikarinen 2018, Danish et al. 2018). See Table 1.

\subsection{Intraclass correlations}

Since data of the current study were gathered at the individual level from both managers and employees, responses should be aggregated. However, the data aggregation decision requires a statistical justification. Intraclass correlations (ICC1 and ICC2) are a statistical technique that can be used to justify data aggregation (Dixon and Cunningham 2006). These correlations are used to compare responses at the individual level with responses at the group level in order to examine response consistency. The criteria used to accept values of ICC1 and ICC2 were 0.12 for ICC1 (Dixon and Cunningham 2006) and 0.7 or higher for ICC2 (Salanova et al. 2005). Results in Table 2 showed good values of a significant F-test attended with an acceptable interclass correlation coefficient of single measures (CCI1) which is higher than 0.12 and acceptable interclass correlation coefficient of average measures (CCI2) which is higher than 0.7.

\subsection{Measures' validity and reliability}

The results shown in Table 3 showed a good level of reliability and validity achieved by the instrument used in the current study; Cronbach's alpha values of all variables ranged from 0.791-0.901 and present a good level of internal consistency. Factor loadings were also higher than 0.6 . Average variance extracted (AVE) values were higher than 0.50 . Finally, values of composite reliability were all higher than 0.70. Cronbach's alpha coefficient of the scale was 0.871 . 
Table 3. Results of validity and reliability

\begin{tabular}{|c|c|c|c|c|c|c|c|}
\hline Variables & Items & Mean & SD & Loading & AVE & $\alpha$ & C.R. \\
\hline \multirow{4}{*}{ 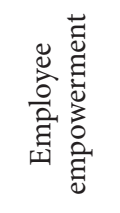 } & EEM1 & 3.48 & 0.78 & 0.71 & \multirow{4}{*}{0.774} & \multirow{4}{*}{0.791} & \multirow{4}{*}{0.89} \\
\hline & EEM2 & 3.67 & 0.48 & 0.83 & & & \\
\hline & EEM3 & 3.49 & 0.66 & 0.74 & & & \\
\hline & Grand & 3.55 & 0.71 & - & & & \\
\hline \multirow{4}{*}{ 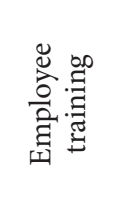 } & ETR4 & 3.88 & 0.58 & 0.81 & \multirow{3}{*}{0.841} & \multirow{3}{*}{0.841} & \multirow{3}{*}{0.86} \\
\hline & ETR5 & 3.54 & 0.90 & 0.77 & & & \\
\hline & ETR6 & 3.70 & 0.77 & 0.84 & & & \\
\hline & Grand & 3.71 & 0.81 & - & & & \\
\hline \multirow{4}{*}{ 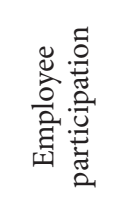 } & EPT7 & 3.61 & 0.74 & 0.77 & \multirow{3}{*}{0.698} & \multirow{3}{*}{0.811} & \multirow{3}{*}{0.79} \\
\hline & EPT8 & 3.74 & 0.69 & 0.76 & & & \\
\hline & ЕРТ9 & 3.80 & 0.74 & 0.70 & & & \\
\hline & Grand & 3.72 & 0.71 & - & & & \\
\hline \multirow{13}{*}{ 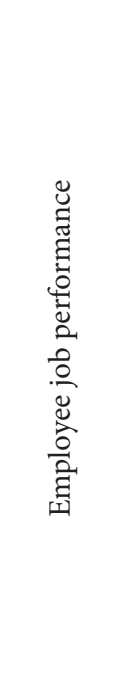 } & EJP1 & 4.01 & 0.74 & 0.69 & \multirow{12}{*}{0.779} & \multirow{12}{*}{0.901} & \multirow{12}{*}{0.87} \\
\hline & EJP2 & 3.21 & 0.95 & 0.82 & & & \\
\hline & EJP3 & 3.58 & 0.88 & 0.73 & & & \\
\hline & EJP4 & 3.99 & 0.74 & 0.71 & & & \\
\hline & EJP5 & 3.45 & 0.81 & 0.74 & & & \\
\hline & EJP6 & 3.68 & 0.58 & 0.83 & & & \\
\hline & EJP7 & 3.47 & 0.60 & 0.81 & & & \\
\hline & EJP8 & 3.46 & 0.54 & 0.72 & & & \\
\hline & EJP9 & 3.80 & 0.55 & 0.80 & & & \\
\hline & EJP10 & 3.68 & 0.49 & 0.76 & & & \\
\hline & EJP11 & 3.58 & 0.68 & 0.68 & & & \\
\hline & EJP12 & 3.49 & 0.55 & 0.70 & & & \\
\hline & Grand & 3.62 & 0.61 & - & & & \\
\hline \multirow{5}{*}{ 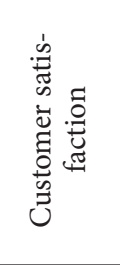 } & CS1 & 3.44 & 0.70 & 0.81 & \multirow{4}{*}{0.810} & \multirow{4}{*}{0.891} & \multirow{4}{*}{0.80} \\
\hline & $\mathrm{CS} 2$ & 3.67 & 0.61 & 0.75 & & & \\
\hline & CS3 & 3.97 & 0.56 & 0.74 & & & \\
\hline & CS4 & 3.84 & 0.67 & 0.89 & & & \\
\hline & Grand & 3.73 & 0.68 & - & - & - & \\
\hline 苟 & Grand & 3.67 & 0.82 & - & - & 0.871 & - \\
\hline
\end{tabular}

\subsection{Normality and collinearity}

Normality distribution and collinearity were examined using Kolmogorov-Smirnov, kurtosis and skewness, the variance of Inflation (VIF) and tolerance statistics. It was noted from the results in Table 4 that the data used for the purpose of this study were normally distributed and free of collinearity related problems since the significant levels of Kolmogorov-Smirnov values were higher than 0.05 , kurtosis values were below 7 , skewness values below -1 , VIF values were below 10 and values were higher than 0.1 .
Table 4. Results of normality distribution and collinearity

\begin{tabular}{|c|c|c|c|c|c|c|}
\hline $\begin{array}{c}\text { Dimen- } \\
\text { sions }\end{array}$ & \multicolumn{2}{|c|}{$\begin{array}{c}\text { Kolmogorov- } \\
\text { Smirnov }\end{array}$} & Kurtosis & $\begin{array}{c}\text { Skew- } \\
\text { ness }\end{array}$ & VIF & $\begin{array}{c}\text { Tole- } \\
\text { rance }\end{array}$ \\
\hline EEM & 1.331 & 0.091 & 1.551 & -0.711 & 2.33 & 0.331 \\
\hline ETR & 1.542 & 0.120 & 0.997 & -0.660 & 1.79 & 0.481 \\
\hline EPT & 1.411 & 0.421 & 0.781 & -0.721 & 1.80 & 0.524 \\
\hline EJP & 1.201 & 0.511 & 1.20 & -0.549 & 2.48 & 0.440 \\
\hline CS & 1.615 & 0.088 & 0.892 & -0.621 & 1.89 & 0.721 \\
\hline
\end{tabular}

\section{Data analysis and results}

\subsection{Intercorrelations matrix}

The results in Table 5 clarified that all dimensions of BOM were positively and significantly interrelated; employee empowerment was correlated to employee training $(\mathrm{r}=0.51$, $\mathrm{P}<0.01)$, employee participation $(\mathrm{r}=0.47, \mathrm{P}<0.01)$. BOM dimensions were also positively and significantly associated with employee job performance and customer satisfaction. Employee job performance was positively and significantly related to employee empowerment $(\mathrm{r}=0.58, \mathrm{P}<0.01)$, employee training $(\mathrm{r}=0.49, \mathrm{P}<0.05)$, and employee participation $(r=0.37, \mathrm{P}<0.01)$. Customer satisfaction was positively and significantly related to employee empowerment $(\mathrm{r}=0.44, \mathrm{P}<0.01)$, employee training $(\mathrm{r}=0.29, \mathrm{P}<0.05)$, and employee participation $(\mathrm{r}=0.40, \mathrm{P}<0.01)$. Finally, employee job performance was positively and significantly related to customer satisfaction $(\mathrm{r}=0.52, \mathrm{P}<0.01)$.

Table 5. Means, standard deviations and colorations of study variables

\begin{tabular}{|l|c|c|c|c|c|}
\hline Variables & EEM & ETR & EPT & EJP & CS \\
\hline EEM & - & & & & \\
\hline ETR & $0.51^{\star *}$ & - & & & \\
\hline EPT & $0.47^{\star \star}$ & $0.37^{\star}$ & - & & \\
\hline EJP & $0.58^{\star \star}$ & $0.49^{\star *}$ & $0.37^{\star *}$ & - & \\
\hline CS & $0.44^{\star *}$ & $0.29^{\star *}$ & $0.40^{\star}$ & $0.52^{\star *}$ & - \\
\hline
\end{tabular}

* Correlation is significant at the 0.05 level

** Correlation is significant at the 0.01 level

\subsection{Goodness-of-fit indices}

Hooper et al. (2008) suggested reporting the most common Goodness-of-fit indices such as Chi-Square statistic/ degrees of freedom $\left(\mathrm{Chi}^{2} / \mathrm{df}\right)$, RMSEA, SRMR, CFI, and one of the parsimony indices. Table 6 displayed that the model achieved a good level of fitness since all indices were in harmony with cutoff criteria.

\subsection{Testing hypotheses}

Structural equation modeling (SEM) was used to test study hypotheses. Figure 2 presented the final model estimated. 
Table 6. Goodness-of-fit results

\begin{tabular}{|c|c|l|l|}
\hline Index & Value & \multicolumn{1}{|c|}{ Cutoff criteria } & \multicolumn{1}{|c|}{ Result } \\
\hline $\mathrm{Chi}^{2} / \mathrm{df}$ & 1.972 & Less than 3 & Accepted \\
\hline $\mathrm{RMSEA}$ & 0.041 & Less than 0.08 & Accepted \\
\hline $\mathrm{SRMR}$ & 0.034 & Less than 0.08 & Accepted \\
\hline CFI & 0.931 & Higher than 0.90 & Accepted \\
\hline NNFI & 0.961 & Higher than 0.90 & Accepted \\
\hline
\end{tabular}

$\mathrm{Chi}^{2} / \mathrm{df}$ : Chi-Square statistic/degrees of freedom, RMSEA: root mean square error of approximation, SRMR: Square Root Mean Residual, CFI: Comparative fit index, NNFI: Non-normed Fit Index

The results supported hypothesis 1 in which employee empowerment was assumed to positively and significantly predict employee job performance $(\beta=0.371$, S.E. $=0.22$, C.R. $=7.13, \mathrm{P}<0.01)$. Hypothesis 2 presumed that employee training is positively related to employee job performance. The hypothesis were accepted $(\beta=0.439$, S.E. $=$ 0.17$, C.R. $=6.22, \mathrm{P}<0.01)$. Hypothesis 3 was also accepted $(\beta=0.290$, S.E. $=0.13$, C.R. $=4.21, P<0.05)$. The results supported the hypothesis that employee empowerment (H4) is positively related to customer satisfaction $(\beta=0.19$, S.E. $=0.11$, C.R. $=3.31, \mathrm{P}<0.05)$. Customer satisfaction was significantly predicted by employee training $(\mathrm{H} 5)(\beta=$ 0.220 , S.E. $=0.20$, C.R. $=3.19, \mathrm{P}<0.01)$ and employee participation (H6) $(B=0.16$, S.E. $=0.09$, C.R. $=3.01, \mathrm{P}<$ $0.01)$. Finally, the results indicated that employee job performance mediated the effect of open book management on customer satisfaction (H7).

\section{Discussion and conclusion}

In this study, a model was developed in order to examine the effects of open book management (employee empowerment, employee training and employee participation)

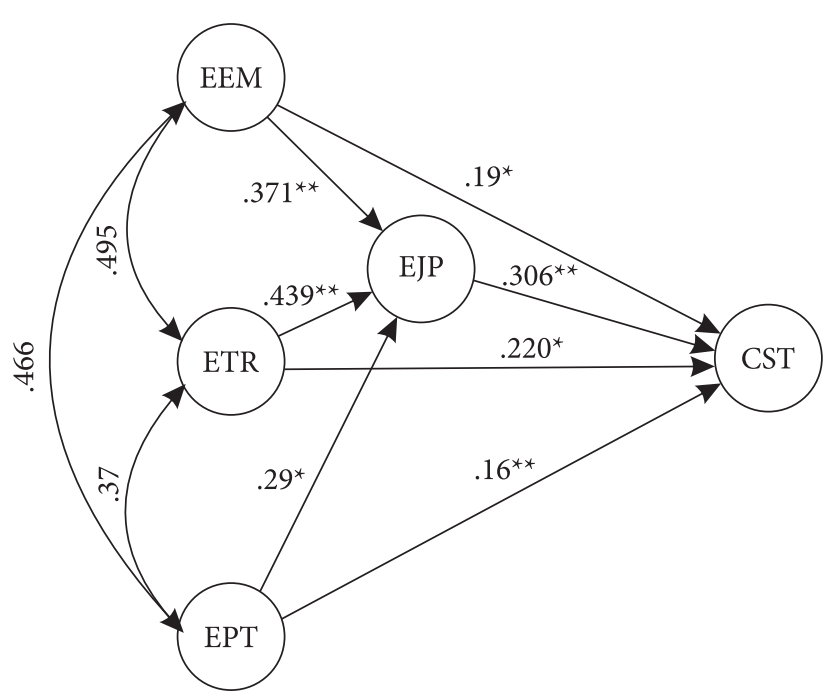

Figure 2. Research conceptual model on customer satisfaction through employee job performance. The findings demonstrated that all dimensions of open book management were positively and significantly interrelated and have significant effects on employee job performance. However, in agreement with Pfeffer and Veiga (1999), the effect of employee training was the highest one. Generally speaking, the positive impact of open book management on employee job performance was found in a recent study conducted by Agbaeze and Nnaji (2017). Particularly, Elnaga and Imran (2013), Al-Mzary et al. (2015) and Padmasiri et al. (2018) reported that employee training was significantly related to employee job performance. Chiang and Hsieh's (2012) verified a positive effect of employee empowerment on employee job performance. In contrast, the positive effect of employee participation in job performance was introduced by Bhatti and Qureshi (2007) and Groen et al. (2016)

Furthermore, the results indicated that all dimensions of open book management have significant effects on customer satisfaction, and employee training was the most efficacious dimension, followed by employee empowerment and employee participation. Yukl and Becker (2006) suggested that employee empowerment in the context of open book management should be supported by training in order to enhance the ability of the employee to use the financial data of the organization. Similar results concerning the effect of open book management dimensions were found in the literature. Rogg et al. (2001), Molina and Ortega (2003) and Chartrungruang et al. (2006) demonstrated a positive effect of employee training on customer satisfaction. Ugboro and Obeng (2000), Peters and Mazdarani (2008) and Isimoya and Bakarey (2013) pointed out a positive impact of employee empowerment on customer satisfaction. Inconsistent with this result, Naeem and Saif (2010) and Jonathan and Johnmark (2012) indicated that there was no relationship between employee empowerment and customer satisfaction.

Finally, the results showed that employee job performance significantly mediated the effect of employee empowerment and employee training as well as employee participation on customer satisfaction. Abbasi and Alvi (2013) concluded a similar result. This result can be explained by the nature of employee job performance as a variable comprised both behavioral and outcome aspects (Yee 2018) by which an employee can directly contribute to the achievement of organizational goals (Rich et al. 2010). Lee et al. (2012) regarded employee job performance as a key factor of customer satisfaction. Gillespie et al. (2008) highlighted the significance of directing organizational goals and strategies to satisfy customers.

In conclusion, this study illustrated that training is more important than empowerment when an organization seeks to enhance employee job performance and to ameliorate 
customer satisfaction. Employee empowerment should be put as second priority after training. This conclusion can be justified by the fact that the empowerment of an undertrained employee is futile. At that point, the desired benefits of empowerment will be not realized. On the other hand, one can come to the conclusion that open book management when introduced as a style of management to support the achievement of organizational goals, employee training, empowerment, performance and participation should be considered as pivotal stakes in the process of open book management implementation.

\section{Research and practice implications}

Two key implications for research and practice were reached on the basis of the results of this study. First, the study examined the effects of OBM dimensions on employee job performance and customer satisfaction. OBM was conceptualized in this study in terms of three dimensions, i.e., employee empowerment, employee training and employee participation in the overall organizational success rather than as a whole construct. On the ground of the results, suggested interventions to improve employee job performance through open book management should put employee training as a first priority since training has the highest effect on employee job performance. Employee training, employee empowerment and employee participation were three components of open book management suggested by Aggarwal and Simkins (2001) in addition to information sharing and management commitment. One of the most important findings of the current study was the arrangement of these components according to priority and importance as follows: employee training, employee empowerment and, finally, employee participation. Second, the results of this study indicated that employee job performance mediated the effect of open book management dimensions on customer satisfaction. Therefore, an organization adopts open book management as a mechanism to increase customer satisfaction should keep tabs on employee job performance in order to ensure an effective practice of OBM.

\section{Limitations and recommendations}

Future research should study new relationships between OBM and other variables such as management trust in employees. Pfeffer and Veiga (1999) stated that organization's financial information can be provided only to trusted employees. On the other hand, the authors confirmed that employee training is a key element when an organization practices OBM, so that employees can understand, interpret and use information. Accordingly, future research should investigate the moderating role of employee training in the relationship between OBM and both employee job performance and customer satisfaction. For Nikzad and
Maryam (2012), a key factor of open book management was information sharing between management and employees. Information sharing as a dimension of open book management was not studied in this study. That is why future research should cover information sharing and its relationships with employee job performance and customer satisfaction. Glew et al. (1995) took open book management as an effort a management makes to give employees the opportunity to participate in the organizational success. Future research, whence, should consider the management commitment and support in the context of open book management.

\section{References}

Abbasi A, Alvi A (2013) Impact of employee characteristics and their performance on customer satisfaction. Science International 25 (2): 387-394.

Agbaeze E, Nnaji P (2017) Evaluation of the impact of Open Book Management on employee performance in selected manufacturing firms in Enugu State, Nigeria. Journal of Applied Sciences and Development (JASD) 8 (1): 18-35.

Aggarwal R, Simkins BJ (2001) Open book “financial” management: a case study of Manco, Inc. Oklahoma State University Working Paper.

Al-Mzary M, Al-Rifai A, Al-Momany M (2015) Training and its impact on the performance of employees at Jordanian universities from the perspective of employees: the case of Yarmouk University. Journal of Education and Practice 6 (2015): 128-140.

Al-Tit A (2015) The effect of service and food quality on customer satisfaction and hence customer retention. Asian Social Science 11 (23): 129-139. https://doi.org/10.5539/ass.v11n23p129

Al-Tit A (2017) Factors affecting the organizational performance of manufacturing firms. International Journal of Engineering Business Management 9: 1-9. https://doi. org/10.1177/1847979017712628

Becker T, Billings R, Eveleth D, Gilbert N (1996) Foci and bases of employee commitment: implications for job performance. Academy of Management Journal 39 (2): 464-482.

Bhatti KK, Qureshi TM (2007) Impact of employee participation on job satisfaction, employee commitment and employee productivity. International Review of Business Research Papers 3 (2): 54-68.

Chartrungruang B, Turner L, King B, Waryszak R (2006) Customer satisfaction, training and TQM: a comparative study of Western and Thai hotels. The Journal of Services Marketing 11 (4): 249-264. https://doi.org/10.1300/J171v05n01_04

Chiang C, Hsieh T (2012) The impacts of perceived organizational support and psychological empowerment on job performance: the mediating effects of organizational citizenship behavior. International Journal of Hospitality management 31 (1): 180-190. https://doi.org/10.1016/j.ijhm.2011.04.011

Danish RQ, Humayon A, Iqbal H, Raza S, Shahid J (2018) The impact of service quality and service value on customer satisfaction through customer bonding: evidence from telecommunication sector. European Online Journal of Natural and Social Sciences: Proceedings 7 (1): 40-47. 
Davis T (1997) Open-book management: its promise and pitfalls. Organizational Dynamics 25 (3): 7-20. https://doi. org/10.1016/S0090-2616(97)90044-9

Dixon MA, Cunningham GB (2006) Data aggregation in multilevel analysis: a review of conceptual and statistical issues. Measurement in Physical Education and Exercise Science 10 (2): 85-107. https://doi.org/10.1207/s15327841mpee1002_2

Elnaga A, Imran A (2013) The effect of training on employee performance. European Journal of Business and Management 5 (4): 137-147.

Evans W, Davis W (2005) High-performance work systems and organizational performance: the mediating role of internal social structure. Journal of Management 31 (5): 758-775. https://doi.org/10.1177/0149206305279370

Gillespie M, Denison D, Haaland S, Smerek R, Neale W (2008) Linking organizational culture and customer satisfaction: results from two companies in different industries. European Journal of Work and Organizational Psychology 17 (1): 112132. https://doi.org/10.1080/13594320701560820

Glew DJ, O’ Leary-Kelly AM, Griffin RW, Van Fleet DD (1995) Participation in organizations: a preview of issues and proposed framework for future analysis. Journal of Management 21 (3): 395-421. https://doi.org/10.1177/014920639502100302

Groen BAC, Wouters MJF, Wilderom CPM (2016) Employee participation, performance, metrics, and job performance: a survey study based on self-determination theory. Management Accounting Research 36: 51-66. https://doi.org/10.1016/j. mar.2016.10.001

Hooper D, Coughlan J, Mullen MR (2008) Structural equation modeling: guidelines for determining model fit. Electronic Journal of Business Research Methods 6: 53-60.

Isimoya A, Bakarey B (2013) Employees' empowerment and customers' satisfaction in insurance industry in Nigeria. Australian Journal of Business and Management Research 3 (5): 1-11. Journal of Business Studies Quarterly 3 (4): 92-104.

Jonathan VL, Johnmark DR (2012) The impact of employee empowerment on customer satisfaction in the Nigerian service organizations (a study of some selected hotels in jos, plateau state). International Journal of Current Research and Review 4 (19): 37.

Kattara H, Weheba D, El-Said O (2008) The impact of employee behavior on customers' service quality perceptions and overall satisfaction. Tourism and Hospitality Research 8 (4): 309-323. https://doi.org/10.1057/thr.2008.35

Lee S, Lee D, Kang C (2012) The impact of high-performance work systems in the health-care industry: employee reactions, service quality, customer satisfaction, and customer loyalty. The Service Industries Journal 32 (1): 17-36. https://doi. org/10.1080/02642069.2010.545397

Liao H, Chuang A (2004) A multilevel investigation of factors influencing employee service performance and customer outcomes. Academy of Management journal 47 (1): 41-58.

Lloyd B, Case J (1998) Open book management: a new approach to leadership. Leadership \& Organization Development Journal 19 (7): 392-396. https://doi.org/10.1108/01437739810242568

Molina JA, Ortega R (2003) Effects of employee training on the performance of North American firms. Applied Economics Letters 10: 549-552. https://doi.org/10.1080/ 1350485032000100297
Naeem H, Saif MI (2010) Employee empowerment and customer satisfaction: empirical evidence from the banking sector of Pakistan. African Journal of Business Management 4 (10): 2028-2031.

Nikzad M, Maryam G (2012) The relationship between open book management and trust with organization financial performance. Procedia Technology 1: 340-344. https://doi. org/10.1016/j.protcy.2012.02.071

Padmasiri MD, Sandamali JGP, Mahalekamge WGS, Mendis MVS (2018) The relationship between training and development and employee performance of executive level employees in apparel organizations. International Invention of Scientific Journal 2 (01): 13-17.

Peters C, Mazdarani E (2008) The impact of employee empowerment on service quality and customer satisfaction in service organizations: a case study of Länsförsäkringar Bank AB: the impact of employee empowerment. Västerås: Mälardalens högskola, 71.

Pfeffer J, Veiga J (1999) Putting people first for organizational success. The Academy of Management Executive 13 (2): 37 48. https://doi.org/10.5465/ame.1999.1899547

Rich B, Lepine J, Crawford E (2010) Job engagement: antecedents and effects on job performance. Academy of management journal 53 (3): 617-635. https://doi.org/10.5465/ amj.2010.51468988

Rogg KL, Schmidt DB, Shull C, Schmitt N (2001) Human resource practices, organizational climate, and customer satisfaction. Journal of Management 27: 431-449. https://doi. org/10.1177/014920630102700403

Roy S, Raju A, Mandal S (2017) An empirical investigation on e-retailer agility, customer satisfaction, commitment and loyalty. Business: Theory and Practice 18: 97-108. https://doi. org/10.3846/btp.2017.011

Salanova M, Agut S, Peiró JM (2005) Linking organizational resources and work engagement to employee performance and customer loyalty: the mediation of service climate. Journal of applied Psychology 90 (6): 1217. https://doi.org/10.1037/00219010.90.6.1217

Schuster J, Carpenter J, Kane M (1996) The power of open book management. NJ: John Wiley and Sons.

Söderlund M, Oikarinen E (2018) Joking with customers in the service encounter has a negative impact on customer satisfaction: replication and extension. Journal of Retailing and Consumer Services 42: 55-64. https://doi.org/10.1016/j. jretconser.2018.01.013

Spreitzer G, Porath C (2012) Creating sustainable performance. Harvard Business Review 90 (1): 92-99.

Sturman M, Cheramie R, Cashen L (2005) The impact of job complexity and performance measurement on the temporal consistency, stability, and test-retest reliability of employee job performance ratings. Journal of Applied Psychology 90 (2): 269. https://doi.org/10.1037/0021-9010.90.2.269

Ugboro I, Obeng K (2000) Top management leadership, employee empowerment, job satisfaction, and customer satisfaction in TQM organizations: an empirical study. Journal of Quality Management 5 (2): 247-272. https://doi.org/10.1016/S10848568(01)00023-2 
Wright T, Cropanzano R, Bonett D (2007) The moderating role of employee positive well-being on the relation between job satisfaction and job performance. Journal of Occupational Health Psychology 12 (2): 93. https://doi.org/10.1037/10768998.12.2.93

Yee L (2018) An analysis on the relationship between job satisfaction and work performance among academic staff in Malaysian private universities. Journal of Arts \& Social Sciences 1 (2): 64-73.
Yukl G, Becker W (2006) Effective empowerment in organizations. Organization Management Journal 3 (3): 210-231. https://doi.org/10.1057/omj.2006.20

Zhang X, Bartol K (2010) Linking empowering leadership and employee creativity: the influence of psychological empowerment, intrinsic motivation, and creative process engagement. Academy of Management Journal 53 (1): 107-128. https://doi.org/10.5465/amj.2010.48037118 